\title{
Social Media Engagement: Content Strategy and Metrics Research Opportunities
}

\author{
Marie-Catherine Perreault \\ École de gestion - Université de Sherbrooke \\ marie-catherine.perreault@usherbrooke.ca
}

\author{
Elaine Mosconi \\ École de gestion - Université de Sherbrooke \\ elaine.mosconi@usherbrooke.ca
}

\begin{abstract}
Social media platforms allow for the integration of online and offline experiences for customers and brand relationships. Firms must understand which moves are the best to engage customers on social platforms. Smartphone's adoption has contributed to the expansion of social media uses and seems to facilitate engagement in online brands' experience. However, previous research reveals no consensus about what customer brand engagement in social media is and how to measure it. The objective here is to identify factors of social media engagement and metrics adopted to define social media brands' content strategy performance. A systematic literature review shows social media engagement as a misunderstood concept related to different levels of customer relationships. Also, findings reveal that the literature has failed to address social media content strategy performance and the metrics adopted. This paper examines and categorizes metrics and opportunities for future research, as well as managerial involvement in social media engagement issues.
\end{abstract}

\section{Introduction}

Businesses work hard to engage customers during the whole product life cycle, which is now referred to as the customer engagement cycle [CEC] [34,55]. Engagement can be expressed by interaction $[35,38,49]$, participation [2,9,22,30,42,53], conversation [52], eWOM $[12,13]$ and other offline and online actions. Online actions, especially those involving social media platforms, play an increasing role in the daily routine. According to Nielsen, the time spent on devices is dominated by smartphones, at $78 \%$ for $18-34$ year olds, $69 \%$ for $35-49$ year olds and $63 \%$ for those $50+$ [40]. With smartphones, we can connect with our favorite brands anytime and anywhere. The reasons users interact with brands are, in order of importance: to find out about products and services; to receive exclusive offers, coupons or other discounts; to show support for their favorite brands; to rate or review a product or service; and to gain access to VIP or members-only events [37]. Firms invest a great deal to build or raise their profile in order to engage and connect potential consumers and brand promoters through their actions on social media. According to some researchers, there are four social media strategies that firms use to connect with customers: the predictive practitioner strategy, the creative experimenter strategy, the social media champion strategy and the social media transformer strategy. Businesses should use a similar approach in each campaign to enable the consumer to recognize them on social media [25]. Research has pointed out factors that contribute to customer engagement $[17,18,20,27,29,30]$, and some authors have also highlighted metrics and procedures to measure engagement on social media [20,26,33,39,45,46,52]. However, few studies have included content and strategies of interaction on social media platforms. Furthermore, companies show little understanding of the customer path of engagement on social media. In this context, the research question that motivates this research is: How is content strategy related to metrics of customer brand engagement on social media platforms? The objective of this paper is to understand factors of engagement and metrics that measure the performance of content strategy on social media platforms. A systematic literature review reveals 51 articles that allow us to understand the complexity of the subject, the growth of interest in measuring engagement, and the absence of consensus on the measurement. Subsequent sections of this article present our research background on brands' engagement and social media brands' engagement. Then, the research method section describes our systematic review approach. The results section presents our bibliometric and content analysis. We end with a discussion of the results, limitations, conclusions and suggestions for future research.

\section{Research Background}

\section{Customer Brand Engagement}

Customer engagement is defined in multiple ways: as a psychological process that will lead to the formation of loyalty; as a behavioral manifestation; and as a psychological state characterized by a degree of vigour, dedication, absorption and interaction [53]. Engagement 
can also be depicted at different levels. A low level of engagement is that of customers that only consume content, and a high level is that of customers that generate content $[2,5]$. There is no consensus about what constitutes engagement in social media or how to measure it. We find definitions about brand engagement, customer engagement, consumer brand engagement and community engagement. The major distinction is that, according to multiple dictionaries, a consumer is someone that has made a purchase, while a follower of the brand does not need to buy to appreciate the brand. Also, most authors did not distinguish between online and offline engagement. However, some authors have contributed to enhancing the literature. The most popular definitions and dimensions in the area of social media engagement are presented in Table 1.

Table 1. Engagement Related Definition

\begin{tabular}{|c|c|c|c|}
\hline Author & Concept & Definition & Dimensions \\
\hline $\begin{array}{l}\text { Hoffman and } \\
\text { Fodor (2010) }\end{array}$ & $\begin{array}{l}\text { CBE: Consumer } \\
\text { Brand Engagement }\end{array}$ & $\begin{array}{l}\text { The CBE is: "The level of a customer's cognitive, emotional } \\
\text { and behavioral investment in specific brand interactions." }\end{array}$ & $\begin{array}{l}\text { Immersion } \\
\text { Passion } \\
\text { Activation }\end{array}$ \\
\hline $\begin{array}{l}\text { Leckie et } \\
\text { al.(2016) }\end{array}$ & $\begin{array}{l}\text { CBE: Customer } \\
\text { Brand Engagement }\end{array}$ & $\begin{array}{l}\text { Consumer Brand Engagement is defined as: "involvement, } \\
\text { participation and self- expression" }\end{array}$ & $\begin{array}{c}\text { Involvement } \\
\text { Participation } \\
\text { Self-expressive brand }\end{array}$ \\
\hline $\begin{array}{l}\text { Agostino et al. } \\
\text { (2016) }\end{array}$ & $\begin{array}{c}\text { Customer } \\
\text { Engagement }\end{array}$ & $\begin{array}{c}\text { Customer Engagement is defined as a: "psychological state } \\
\text { that occurs by virtue of interactive, cocreative customer } \\
\text { experiences with a focal agent/object (e.g., a brand) in focal } \\
\text { service relationships" }\end{array}$ & NA \\
\hline $\begin{array}{l}\text { Kumar et al. } \\
(2010)\end{array}$ & $\begin{array}{l}\text { CEV: Customer } \\
\text { Engagement Value }\end{array}$ & $\begin{array}{l}\text { Engagement is defined as: "Active inter-actions of a customer } \\
\text { with a firm, with prospects and with other customers, whether } \\
\text { they are transactional or nontransactional." In addition, they } \\
\text { said: "Engagement is also seen as a way to create customer } \\
\text { interaction and participation." }\end{array}$ & $\begin{array}{l}\text { Customer: } \\
\text {-purchasing behaviour } \\
\text { - referral behaviour } \\
\text { - influencer behaviour } \\
\text { - knowledge behaviour }\end{array}$ \\
\hline $\begin{array}{l}\text { van Doorn et } \\
\text { al. (2010) }\end{array}$ & $\begin{array}{l}\text { CEB: Customer } \\
\text { Engagement } \\
\text { Behaviour }\end{array}$ & $\begin{array}{c}\text { Engagement brand behaviours are defined as those which: "go } \\
\text { beyond transactions, and may be specifically defined as a } \\
\text { customer's behavioural manifestations that have a brand or } \\
\text { firm focus, beyond purchase, resulting from motivational } \\
\text { drivers" }\end{array}$ & $\begin{array}{l}\text { Valence } \\
\text { Form/Modality } \\
\text { Scope } \\
\text { Nature of impact } \\
\text { Customer goals }\end{array}$ \\
\hline
\end{tabular}

In this way, we have included brand and consumers' engagement in our definition in order to widen the scope of online engagement. While social media customer brand engagement has not been defined, the definition that is the closest is the following: Customers engage in a number of behaviours that strengthen their relationship with the brand, which go beyond the traditional customer loyalty measures, such as frequency of visits, purchasing behaviour, and intended behaviours, [such as sharing, commenting and liking the brand page]. [18].

Furthermore, loyalty is a form of engagement that frequently recurs in the literature [22,23,44,53]. For some authors, loyalty is one step further than engagement (De Vries and Carlson 2014). Loyalty is seen as the customer returning to interact with the brand while engagement includes the initial action of becoming a follower. These actions taken by brands are referred to as activeness [57]. Also, engagement is often represented by interaction $[33,38,49]$ and participation $[2,7,22,42,53]$ in an online and offline world. For various authors, content is the instrument that stimulates interaction with the brands [44]. Research shows that engagement performance is correlated with brand financial performance [4].

\section{Customer Brand Engagement in Social Media}

Social media or social networking sites (SNS) are now part of our routine. People wake up and open their accounts to follow their news, friends and family life or to create content [40]. According to the Marketing Science Institute, $46 \%$ of social network users discuss news stories and half of Facebook participants share news from external links (MIS 2016). The power is all in the hands of customers since online social networks have emerged more as a platform for user-distributed content or can be seen as a two-way communication platform [4,57]. According to Khan (2015), social media may be described as follows: many-to-many, participatory, user owned, conversational, open, mass collaborative, relationship oriented, and free and easy to use [29]. The author distinguishes between two types of social media: static and dynamic (reaction in real time) [29]. Social media are also defined as: "online platforms where users chat, share videos and pictures, companies make their fan pages and many more" [46]. These 
actions can also be perceived as measures of engagement in social media. Indeed, researchers and practitioners have defined engagement in social media as the action of liking, commenting and sharing content from the brand [17,18,28,39,40,41,46,50,57]. These actions can be categorized as behaviour manifestations [54]. Therefore, the action of buying a product is not the only way to measure engagement in social media platforms [10].

Another kind of behaviour seen with social media's arrival is the eWOM, a form of interaction. Social media made the transfer of information to others easier. eWOM is defined by some authors as any positive or negative statements about a product or company made by potential, current, or former customers, which are made available to a multitude of people and institutions via the Internet [13]. Khan also categorized social media's actions and metrics as: like, dislike, share, visits, view, clicks, tagging, mentions, hovering, checkin, pinning, embedding, endorsement, uploading, and downloading [27], described in Table 2.

Table 2. Metrics Used on Social Media Platforms

\begin{tabular}{|l|l|}
\hline Metric & Features that allow users to \\
\hline Like & $\begin{array}{l}\text { Express their positive feelings of liking } \\
\text { content. }\end{array}$ \\
\hline Dislike & Express their negative feelings about content. \\
\hline Share & Distribute content to their social network. \\
\hline Visit & Count the number of website visitors. \\
\hline View & The number of times content has been seen. \\
\hline Click & $\begin{array}{l}\text { Count the number of clicks on a hyperlink } \\
\text { content. }\end{array}$ \\
\hline Tag & Assign content to a person. \\
\hline Hover & Move the cursor over social media content. \\
\hline Check-In & Announce and share their arrival at a location. \\
\hline Pin & Show interesting content at the top of the page. \\
\hline Embed & $\begin{array}{l}\text { Incorporate social media content into a blog or } \\
\text { website. }\end{array}$ \\
\hline $\begin{array}{l}\text { Endorse- } \\
\text { ment }\end{array}$ & Approve other people, products or content. \\
\hline $\begin{array}{l}\text { Upload } \\
\text { Download }\end{array}$ & Add content to a social media platform. \\
\hline
\end{tabular}

These metrics are one way to measure engagement and can be seen as predictors of customers' motivation to consume more [55] or their responsiveness to brands [52]. The real challenge in social media is to quantify the return from each published content [45]. ROI aren't the right metrics to measure engagement according to some practitioners [18]. There are three objective categories for metrics: brand awareness, brand engagement, and word-of-mouth [19] These three categories include number of fans, likes, comments and shares, but also metrics such as the valence of video and the number of embeddings [41]. It seems that there are several measures in the literature for social media brand engagement, but a lack of consensus about how and when to use them. There is a need to better understand how metrics have been adopted to measure social media engagement.

\section{Research Method}

To perform a systematic literature review and to answer our research question, we used the following research chain: (Engagement OR Participation OR Interaction OR E-Participation OR Conversation OR "Customer Engagement" OR "Customer Brand Engagement") AND ("Social Media" OR "Social Network" OR "Social Web" OR "Web 2.0" OR "Social Networking"). Keywords were selected after reading key articles in the domain of engagement in social media. While we found four ways to define engagement, participation, interaction, conversation and eWOM, we consider that eWOM is a form of interaction. Consequently, we have not included eWOM as a single keyword in our research chain. We included brand and consumer engagement for a widespread consideration of online engagement. This chain has been applied to four databases: ABI/INFORM, Science Direct, Scopus and Business Source Complete, explaining why some major papers on social media engagement published in other sources have been excluded. Time and access are the two criteria that justify the choice of the four databases. They provided us with 287 articles. There were 176 duplicate articles that have been eliminated to give us abstracts of 111 articles to read. Inclusion criteria finally helped us eliminate 60 articles that were not directly related to the subject illustrated in Figure 1 and Table 3.

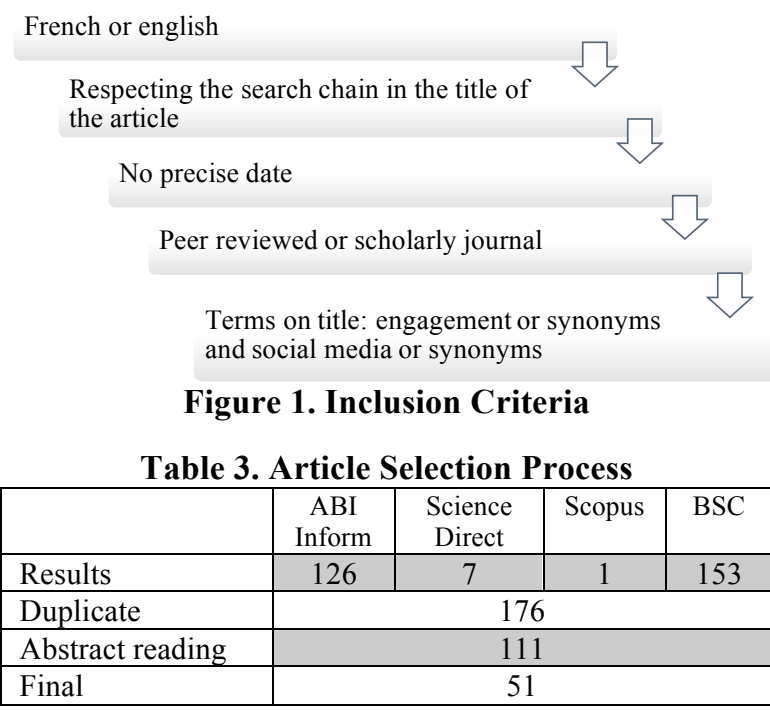

The papers selected were organized in an Excel datasheet with topics inspired by another systematic literature review [8] to better understand social media content strategies and metrics. 


\section{Results}

\subsection{Results analysis}

The analysis of the results presents the bibliometric information on articles in five categories: by publication year, methodological approaches and data sources, journal titles, industrial sectors mentioned and countries of respondents.

\section{Temporal view of publication}

Researchers used to look at engagement satisfaction as a metric and objective. Increasingly, however, customer engagement has become an attractive subject to complement or replace satisfaction [43,52,55]. Results show that research on the topic has been increasing since the beginning of 2011. Readers should note that the article extraction was done in January 2017. Figure 2 presents all this information.

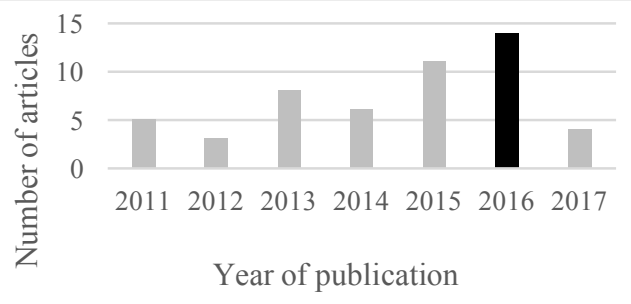

Figure 2. Timeline of Publication

\section{Sources, Approaches and Methodology}

Articles in the area of social media engagement use multiple sources and approaches to obtain results. Some research has used mixed methods. Results show two popular categories of process: quantitative content analysis using metrics to get results, and quantitative content analysis using software to extract data. Quantitative surveys ask consumers about their preferred engagement approach. The qualitative approach is the least popular methodology. As mentioned in the background section, research on the topic is still broadly trying to understand engagement in social media rather than delving deeper into the subject with interviews.

Table 4 presents the distribution of sources for quantitative and qualitative approaches.

Table 4. Distribution of Sources and Approaches

\begin{tabular}{|c|c|c|}
\hline $\begin{array}{c}\text { Data } \\
\text { sources }\end{array}$ & $\begin{array}{c}\text { Qualitative } \\
\text { approach }\end{array}$ & $\begin{array}{c}\text { Quantitative } \\
\text { approach }\end{array}$ \\
\hline $\begin{array}{c}\text { Primary } \\
\text { data }\end{array}$ & $\begin{array}{c}\text { Interview: } 3 \\
\text { Focus groups: } 1 \\
\text { Netnography: } 1 \\
\text { Neuroscience: } 1\end{array}$ & Surveys: 23 \\
\hline $\begin{array}{c}\text { Secondary } \\
\text { data }\end{array}$ & $\begin{array}{c}\text { Literature review: } 2 \\
\text { Content analysis: } 2\end{array}$ & Content analysis: 20 \\
\hline NA & & 7 \\
\hline Total & 9 & 38 \\
\hline
\end{tabular}

\section{Journal Sources Overview}

Three types of journals were utilized: marketing journals, technological journals, and psychological journals. With 51 published articles, only seven journals have had at least two of these publications since January 2017. This result supports the hypothesis that researchers are still in an exploratory phase.

Table 5 displays these journals.

Table 5. Journals With at Least 2 Publications

\begin{tabular}{|l|c|}
\hline \multicolumn{1}{|c|}{ Journals } & Nb \\
\hline Journal of Interactive Advertising & 3 \\
\hline Journal of Advertising Research & 2 \\
\hline Cyberpsychology, Behaviour, and Social Net. & 2 \\
\hline Journal of Marketing Management & 2 \\
\hline Journal of Product \& Brand Management & 2 \\
\hline $\begin{array}{l}\text { Journal of the Association for Information Science } \\
\text { and Technology }\end{array}$ & 2 \\
\hline Strategic Direction & 2 \\
\hline
\end{tabular}

\section{Industrial Sectors}

A systematic literature review shows that $23.5 \%$ of research has mentioned an industrial sector. The other articles have not mentioned any industry (NA). This result reinforces the hypothesis that researchers are trying to understand social media engagement at large before trying to apply more context to their research. Those industries specified are listed in Table 6.

Table 6. Distribution of Industrial Sectors

\begin{tabular}{|l|c|}
\hline Industrial sectors & Nb \\
\hline Multiple industries in the same & 2 \\
\hline Destination and Tourism & 2 \\
\hline Education & 1 \\
\hline Insurance & 1 \\
\hline Politics & 1 \\
\hline Renewable Energy Sources (RESs) & 1 \\
\hline Sports & 1 \\
\hline Television and Media & 1 \\
\hline The Metropolitan Transit Authority & 1 \\
\hline Carbonated-soft-drinks (CSD) & 1 \\
\hline NA & 39 \\
\hline
\end{tabular}

\section{Countries}

When looking at the countries sampled, the report shows that the United States is dominant. $25.5 \%$ of the respondents were from the United States, with China in second place. A mixture of countries is popular in the area of social media engagement. Five studies had respondents from more than one country. Also, 39\% of studies have not mentioned the sampled country. When looking at the authors' countries, we saw that $41 \%$ came from the United States, followed by Australia and Germany. Only one study used cultural impact as a variable in the interaction with brands on social media [52]. 


\subsection{Summary of Results}

The next section presents the 51 articles' analyzed content in terms of four themes: the main theoretical foundations adopted, all factors and antecedents of engagement identified, the social media platforms mentioned, and metric measures adopted to evaluate engagement.

\section{Theoretical foundations}

Most of these papers were lacking in some respect. The most popular theory employed was the Use and Gratification Theory. This was created to cover the human aspect of media use, with the assumption that users have control over their actions. Most research constructs models in three steps: firstly, the antecedents of media use; secondly, the impact of antecedents on the attitude towards the media; and thirdly, the consequences of this attitude on media use. The most popular theoretical models adopted by authors are The Diffusion of Innovation Theory by Rogers 1983, the Technology of Acceptance Model (TAM) by Davis 1986, and the Theory of Reasoned Action by Fishbein \& Ajzen 1967. Authors have also adopted many other theoretical foundations, including the hierarchy of effects; Attention, Interest, Desire and Action (AIDA) concepts; contagion theory; and social exchange theory. The dimensions of individualism and collectivism were also used once. This result reveals a gap between the old-fashioned framework that papers had to present and the absence of a supporting theory for this new area of research. Nonetheless, studies that used models succeeded in achieving their objectives.

\section{Factors and Antecedents}

There is no supporting background for theoretical foundations that can help researchers determine the best factors. There are online and offline variables. Most researchers measure online social media engagement, while only two studies consider offline variables such as gross revenue offline [38], and intention to purchase offline and online [24]. A large number of variables are used to understand factors and antecedents of online social media engagement. As dependent variables, we often saw intention to use, intention to purchase and intention to engage. Also, loyalty, participation and interaction are employed as dependent variables of engagement. Instead of asking questions about intention, some researchers used the following metrics to measure engagement as a dependent variable: like, share, comment, click-through rate and conversation rate. We identified four types of antecedents, as illustrated in Figure 4: brands' features and social media platform characteristics, technical features of posts and individual characteristics.

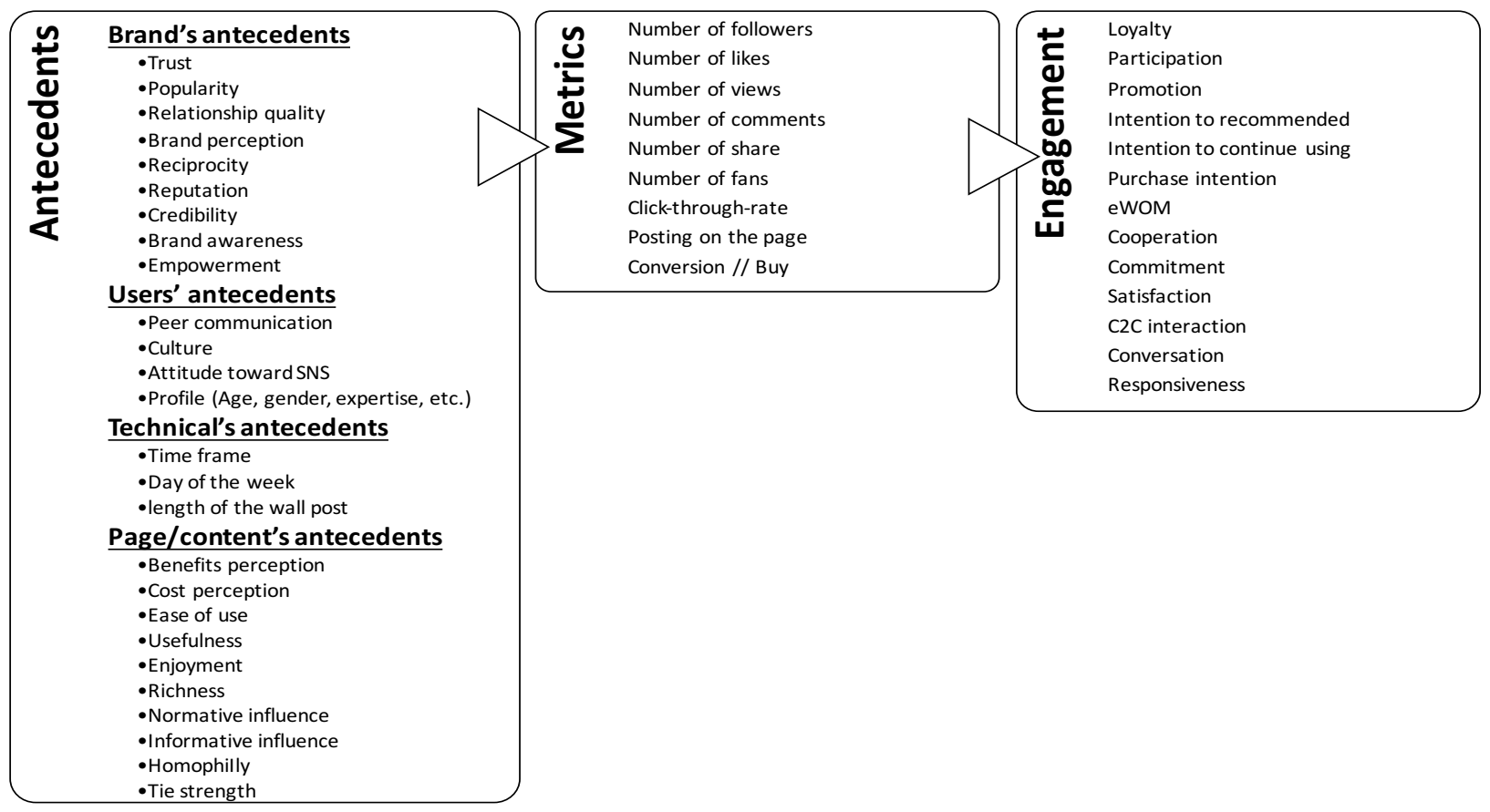

Figure 3. Framework of Factors of Customer Brand Engagement on Social Media

We organized them into three categories: 1) the antecedents also named by other researchers' features, i.e., the characteristics of brands, pages, users and technical antecedents; 2) metrics - which are the actions to measure engagement on social media; and 3) the different ways online engagement could be represented. Figure 4 shows that individual characteristics and social 
media platform characteristics are related to social media metrics and engagement.

\section{Social Media Platforms}

As we are looking for engagement in social media, it was necessary to talk about social networking platforms. $63 \%$ of studies mentioned the platforms that were analyzed. Among those, results show that Facebook is the most popular platform analyzed to understand engagement. After this, the most popular category includes research that didn't mention a specific platform. This is interesting, given that there are different types of social media and they cannot be used in the same way. They have multiple features that make the engagement measurement unique in each. Twitter, My space and YouTube are the ones that emerged from the group since research had started being published in 2011. This result shows that social media engagement needs a wind of change to look at new platforms like Snapchat, Pinterest and Instagram that are gaining ground. Figure 4 presents the social media platforms mentioned.

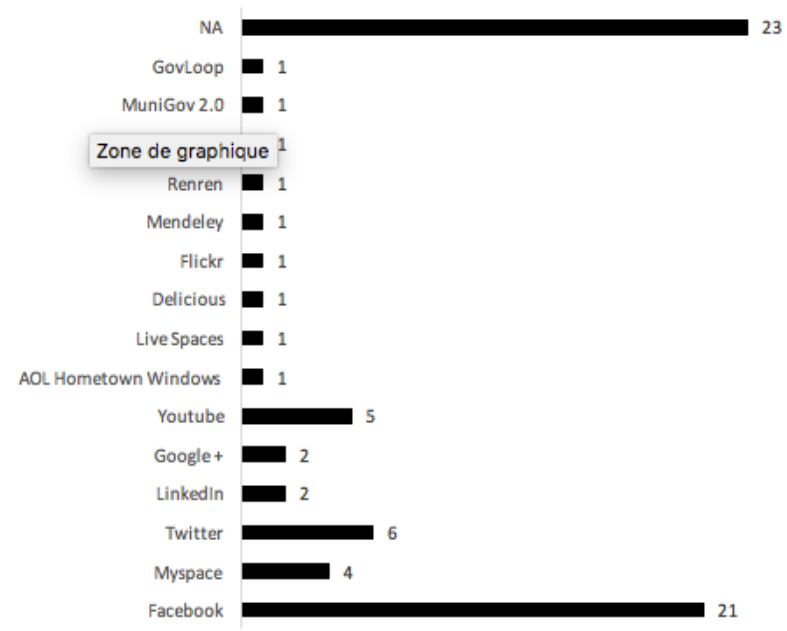

Figure 4. Social Media Platforms Mentioned

\section{Measuring or Using Metrics to Evaluate Engagement}

Some metrics have been defined by authors to measure social media engagement. However, the metrics used by researchers do not explore all the possibilities in the world of social media [27]. The most common are Facebook metrics such as like, comment, share and view. Some use content analysis to measure the numbers of each of these metrics, and others ask consumers questions about actions and intentions. We can see that the most popular are those easiest to measure and those coming from older platforms. In Table 7, articles have been classified by the metrics they use to measure social media engagement. Some metrics have not been mentioned. These include dislike, pinning, visitors, visits, revisits, embeds, hovering, endorsement, check-in and tagging.

Table 7. Metrics Mentioned in Papers

\begin{tabular}{|l|l|}
\hline List of metrics & \multicolumn{1}{|c|}{ References } \\
\hline Like & {$[26,33,38,45,48,50,51]$} \\
\hline Share & {$[39,48,50,51,56]$} \\
\hline View & {$[9,32,39,50,51]$} \\
\hline Clicks & {$[33,47,51]$} \\
\hline Follow & {$[3,39,44]$} \\
\hline Ratios & {$[2]$} \\
\hline Comment & {$[9,21,26,32,33,39,44,47,49,50]$} \\
\hline Conversion rate & {$[39,52]$} \\
\hline Mentions & {$[39]$} \\
\hline Upload \& download & {$[50,51]$} \\
\hline
\end{tabular}

In our in-depth analysis of the literature, we have identified factors of customer brand engagement that are related to metrics. Table 8 presents metrics to measure engagement as a dependent variable.

Table 8. Measures of Engagement

\begin{tabular}{|c|c|c|}
\hline References & Metrics & Engagement \\
\hline $\begin{array}{l}\text { Rapp et al. } \\
\text { (2013) }\end{array}$ & $\begin{array}{l}\text { Number of Likes } \\
\text { Number of comments } \\
\text { Number of followers } \\
\text { Length of the wall post }\end{array}$ & Popularity \\
\hline $\begin{array}{l}\text { Tsai and Men } \\
(2013-2017)\end{array}$ & $\begin{array}{l}\text { Click-through rate } \\
\text { Conversion rate }\end{array}$ & $\begin{array}{c}\text { Affiliation } \\
\text { Conversation } \\
\text { Resnponsiveness }\end{array}$ \\
\hline $\begin{array}{l}\text { Kabadayi and } \\
\text { Price (2014) }\end{array}$ & $\begin{array}{c}\text { Liking } \\
\text { Commenting }\end{array}$ & $\begin{array}{c}\text { Communicating } \\
\text { Broadcasting }\end{array}$ \\
\hline $\begin{array}{l}\text { Maiz et al. } \\
\text { (2016) }\end{array}$ & $\begin{array}{l}\text { Number of clicks and } \\
\text { comments }\end{array}$ & $\begin{array}{c}\text { Social } \\
\text { Interactions }\end{array}$ \\
\hline $\begin{array}{l}\text { Howard et al. } \\
(2016)\end{array}$ & $\begin{array}{l}\text { Posting on the page } \\
\text { Commeting post } \\
\text { Replying to comment }\end{array}$ & Engagement \\
\hline $\begin{array}{l}\text { Oh et al. } \\
(2016)\end{array}$ & $\begin{array}{l}\text { Number of followers } \\
\text { Number of tweet } \\
\text { Number of FB Likes } \\
\text { Numbers of other FB } \\
\text { profiles mentioning } \\
\text { Number of views } \\
\text { Number of comments }\end{array}$ & $\begin{array}{c}\text { Economic } \\
\text { performance }\end{array}$ \\
\hline $\begin{array}{l}\text { Schivinski et } \\
\text { al. (2016) }\end{array}$ & $\begin{array}{c}\text { Read posts } \\
\text { Read fanpages } \\
\text { Watch pictures } \\
\text { Follow blogs } \\
\text { Follow brand } \\
\text { Comment on videos } \\
\text { Comment on post } \\
\text { Comment on pictures } \\
\text { Sahre brand posts } \\
\text { Like pictures } \\
\text { Like posts } \\
\text { Initiate posts } \\
\text { Post pictures } \\
\text { Write review } \\
\text { Write posts } \\
\text { Post videos }\end{array}$ & $\begin{array}{l}\text { Consumption } \\
\text { Contribution } \\
\text { Creation }\end{array}$ \\
\hline
\end{tabular}




\section{Limitations}

Many studies had limitations that were identified in the 51 articles. The absence of theoretical foundations for the majority of studies is considered a limitation. Thus, variables, in some cases, were not explained as they should have been. Several studies had insufficient discussions of their limitations and future research prospects. Details were missing about the choice of metrics, and content analysis strategy, and there was bias regarding the software used and sample features. The data collection section was also neglected in some cases. Researchers failed to explain all the processes they used, thus limiting replicability. Finally, the most serious limitation is the lack of use of practitioners. Some studies forgot to talk about recommendations for businesses.

\section{Discussion and Conclusion}

Firstly, our systematic literature review allowed us to identify numerous opportunities for research in the social media engagement area. There are many recommendations for such research, including mixed methods or mixed approaches, and incorporating qualitative data to reflect the voice of customers. This would be particularly enlightening, given that most studies used quantitative data, such as surveys and content analysis, to obtain their results [see table 8] $[5,53]$. Only research using metrics used content analysis. Also, the metrics used to measure engagement are only some of the possibilities, as shown in Table 5. According to authors in this area, previous studies have explored social media engagement focusing only on its strength and have not explored the nature of the engagement behaviour and the link between content strategy and metrics [51]. For some, using content analysis is the solution, which means looking at what customers like to share and talk about, and what is the best moment for them to engage, and not merely looking at likes and comments as the only metrics [9,26]. Therefore, researchers should use mixed methods to link qualitative and quantitative data to present a more complete picture. There should be a link between what customers are saying and the metrics, but it does not signify that this is always a perfect correlation. For example, brands producing humorous advertisements that go viral will have a high level of engagement observable in the metrics, but this does not imply that consumers will engage more with the brand, apart from the entertainment itself. However, there is no mention of customer brand engagement factors related to content strategy. The literature does not allow us to present this link as researchers are still trying to understand basic factors instead of relations.

Secondly, most authors agree that social media engagement needs more attention from researchers.
Some have suggested testing the correlation between engagement and purchase intention, peer communication and trust $[22,50]$. Along the same lines, there was mention of the message valence as a variable to test $[9,15,36,52]$. In addition, researchers proposed devoting greater attention to acquisition and retention factors and to analyzing the impact of emotions on commitment levels [8].

Brands are also an issue for many researchers. They recommended using larger sets of brands, and different degrees of brand maturity, and linking the online and offline brand experience [16]. The most common limitation is the small sample that doesn't allow researchers to generalize about their results $[11,12,24,31,35,48]$. Consequently, studies should explore a broader array of sample types and sizes.

Thirdly, culture is a variable that has been mentioned by some researchers as a weakness. Cross-national samples that allow researchers to generalize results are suggested [1,14,51]. Multiple studies did not mention the source of the samples. Social media allow people from around the world to connect, but this does not mean that we are all acting the same way. A study comparing two countries shows that there are differences in Chinese and American engagement actions on social media [51]. Researchers should consider this bias in their sections on the limitations of their studies, but should also describe their samples more thoroughly. Education level, country and age are three examples of the types of information that would allow us to have a clearer overview of samples and their cultures [23]. Most studies suggest describing users' profiles and working on thoroughly understanding customers' behaviours on social media.

Fourthly, the individual's characteristics and the social media platform characteristics should be analyzed to understand the connection between these features and their impact on engagement metrics and brand performance. Various factors have been suggested and tested by researchers but, so far, none have been linked to content strategy. Future research should take this path to explore the real basis of social media, the content itself.

Finally, we need to consider industry and product mentions. Most studies have explored social media engagement largely without concern for industry or product exceptions $[35,52]$. It is interesting to see the big picture of social media engagement, but the suggestions are not useful when it comes to applying them to different products or industries. Regarding low involvement products (low price and quick purchase), there are users that follow brands and they are engaging in a way that will probably lead to a purchase. In a different manner, high involvement products on social media also have a lot of followers and engage users, but 
don't have the same impact on purchase intention. This is what we call brand promoters. These people are actively engaging with a brand on social media but will not buy products because they don't have the budget, it is not available in their country, etc. Thus, social media engagement research should try to distinguish between social media promoters' engagement and social media buyers' engagement. This distinction is important for brands to compare their desire to raise their profile with their financial objective.

The main objective of this paper is to understand how researchers have defined factors of engagement and metrics that measure brands' content performance in their social media pages. The academic contribution is that this systematic literature review allowed us to show engagement antecedents and to categorize social media metrics. These initiatives helped researchers make the point about what has been done and how to contribute to this popular topic of social media engagement. As an attractive area that constantly changes, researchers have a lot to add to support businesses in their quest to increase social media engagement. The managerial contribution is to show where the businesses' priorities should be. The focus should be on how to measure engagement and which content strategies promote engagement. Firms should see a return on investment for each dollar invested. With the multiplication of new social networking sites, businesses must make an effort to understand the context and impacts of each category to customize their communication. Now, researchers and firms have to devote time to establishing the most important factors and antecedents, the correct metrics to measure engagement and the platforms that will allow them to target the right audience.

\section{References}

[1] Agostino, D., Arena, M., Catalano, G., and Erbacci, A. Public engagement through social media: the spending review experience. Public Money \& Management 37, 1 (2017), 55-62.

[2] Agostino, D. and Arnaboldi, M. A Measurement Framework for Assessing the Contribution of Social Media to Public Engagement. Public Management Review 18, 9 (2016), 1289-1307.

[3] Ashley, C. and Tuten, T. Creative Strategies in Social Media Marketing: An Exploratory Study of Branded Social Content and Consumer Engagement. Psychology \& Marketing 32, 1 (2015), 15-27.

[4] Blaschke, S. and Veh, A. Strategies for the use of social media in stakeholder conversations. Strategien für den Einsatz sozialer Medien in Stakeholderkonversationen. 75, 6 (2015), 401-412.
[5] Boulianne, S. Social media use and participation: a meta-analysis of current research. Information, Communication \& Society 18, 5 (2015), 524-538.

[6] Brodie, R.J., Hollebeek, L.D., Juric, B., and Ilic, A. Customer Engagement: Conceptual Domain, Fundamental Propositions, and Implications for Research. Journal of Service Research : JSR; Thousand Oaks 14, 3 (2011), 252.

[7] Brown, M., Alkadry, M., and Resnick-Luetke, S. Social Networking and Individual Perceptions: Examining Predictors of Participation. Public Organization Review 14, 3 (2014), 285-304.

[8] Busalim, A.H. and Hussin, A.R.C. Understanding social commerce: A systematic literature review and directions for further research. International Journal of Information Management 36, 6, Part A (2016), 10751088 .

[9] Campbell, C., Pitt, L.F., Parent, M., and Berthon, P.R. Understanding Consumer Conversations Around Ads in a Web 2.0 World. Journal of Advertising 40, 1 (2011), 87-102.

[10] Chauhan, K. and Pillai, A. Role of content strategy in social media brand communities: a case of higher education institutes in India. The Journal of Product and Brand Management; Santa Barbara 22, 1 (2013), 4051.

[11] Chu, S.-C. Viral Advertising in Social Media: Participation in Facebook Groups and Responses Among College-Aged Users. Journal of Interactive Advertising 12, 1 (2011), 30-43.

[12] Chu, S.-C. and Kim, Y. Determinants of consumer engagement in electronic word-of-mouth (eWOM) in social networking sites. International Journal of Advertising 30, 1 (2011), 47-75.

[13] Daugherty, T. and Hoffman, E. eWOM and the importance of capturing consumer attention within social media. Journal of Marketing Communications; London 20, 1-2 (2014), 82.

[14] De Vries, N.J. and Carlson, J. Examining the drivers and brand performance implications of customer engagement with brands in the social media environment. Journal of Brand Management 21, 6 (2014), 495-515.

[15] Dessart, L., Veloutsou, C., and Morgan-Thomas, A. Consumer engagement in online brand communities: a social media perspective. Journal of Product \& Brand Management 24, 1 (2015), 28-42.

[16] Di Gangi, P.M. and Wasko, M. Social Media Engagement Theory: Exploring the Influence of User 
Engagement on Social Media Usage. Journal of Organizational \& End User Computing 28, 2 (2016), 53-73.

[17] van Doorn, J., Lemon, K.N., Mittal, V., et al. Customer Engagement Behavior: Theoretical Foundations and Research Directions. Journal of Service Research: JSR; Thousand Oaks 13, 3 (2010), 253.

[18] Gummerus, J., Liljander, V., Weman, E., and Pihlström, M. Customer engagement in a Facebook brand community. Management Research Review: MRN; Patrington 35, 9 (2012), 857-877.

[19] Hoffman, D.L. and Fodor, M. Can you measure the ROI of your social media marketing? MIT Sloan Management Review 52, 1 (2010), 41-49.

[20] Hollebeek, L. Exploring customer brand engagement: definition and themes. Journal of Strategic Marketing; London 19, 7 (2011), 555.

[21] Howard, P.N., Savage, S., Saviaga, C.F., Toxtli, C., and Monroy-Hemández, A. Social Media, Civic Engagement, and the Slacktivism Hypothesis: Lessons from Mexico's "El Bronco." Journal of International Affairs 70, 1 (2016), 55-73.

[22] Hu, K.-C., Lu, M., Huang, F.-Y., and Jen, W. Click "Like" on Facebook: The Effect of Customer-tocustomer Interaction on Customer Voluntary Performance for Social Networking Sites. International Journal of Human-Computer Interaction 33, 2 (2017), 135-142.

[23] Hudson, S., Huang, L., Roth, M.S., and Madden, T.J. The influence of social media interactions on consumer-brand relationships: A three-country study of brand perceptions and marketing behaviors. International Journal of Research in Marketing 33, 1 (2016), 27-41.

[24] Hutter, K., Hautz, J., Dennhardt, S., and Füller, J. The impact of user interactions in social media on brand awareness and purchase intention: the case of MINI on Facebook. The Journal of Product and Brand Management; Santa Barbara 22, 5/6 (2013), 342-351.

[25] James Wilson, H., Guinan, P., D. Weinberg, B., and Parise, S. What's Your Social Media Strategy? Harvard Business Review, (2011).

[26] Kabadayi, S. and Price, K. Consumer - brand engagement on Facebook: liking and commenting behaviors. Journal of Research in Interactive Marketing; Bradford 8, 3 (2014), 203-223.

[27] Khan, G.F. Seven Layers of social media analytics : Mining Business Insights from Social Media Text,
Actions, Networks, Hyperlinks, Apps, Search Engine, and Location. 2015.

[28] Kim, Y., Wang, Y., and Oh, J. Digital Media Use and Social Engagement: How Social Media and Smartphone Use Influence Social Activities of College Students. CyberPsychology, Behavior \& Social Networking 19, 4 (2016), 264-269.

[29] Kumar, V., Aksoy, L., Donkers, B., Venkatesan, R., Wiesel, T., and Tillmanns, S. Undervalued or Overvalued Customers: Capturing Total Customer Engagement Value. Journal of Service Research : JSR; Thousand Oaks 13, 3 (2010), 297.

[30] Leckie, C., Nyadzayo, M.W., and Johnson, L.W. Antecedents of consumer brand engagement and brand loyalty. Journal of Marketing Management; Helensburg 32, 5-6 (2016), 558.

[31] Lee, D., Hyuk Soo Kim, and Jung Kyu Kim. The Impact of Online Brand Community Type on Consumer's Community Engagement Behaviors: Consumer-Created vs. Marketer-Created Online Brand Community in Online Social-Networking Web Sites. CyberPsychology, Behavior \& Social Networking 14, 1/2 (2011), 59-63.

[32] Lim, Y., Chung, Y., and Weaver, P.A. The impact of social media on destination branding: Consumergenerated videos versus destination marketer-generated videos. Journal of Vacation Marketing; London 18, 3 (2012), 197.

[33] Maiz, A., Arranz, N., and Fdez. de Arroyabe, J.C. Factors affecting social interaction on social network sites: the Facebook case. Journal of Enterprise Information Management; Bradford 29, 5 (2016), 630649.

[34] Malhotra, A., Malhotra, C.K., and See, A. How to Create Brand Engagement on Facebook. MIT Sloan Management Review; Cambridge 54, 2 (2013), 18-20.

[35] Moon, J.H., Kim, E., Choi, S.M., and Sung, Y. Keep the Social in Social Media: The Role of Social Interaction in Avatar-Based Virtual Shopping. Journal of Interactive Advertising 13, 1 (2013), 14-26.

[36] Muralidharan, S. and Men, L.R. How Peer Communication and Engagement Motivations Influence Social Media Shopping Behavior: Evidence from China and the United States. CyberPsychology, Behavior \& Social Networking 18, 10 (2015), 595-601.

[37] Nielsen. 2016 Nielsen Social media Report. Nielsen, 2016.

[38] Oh, C., Roumani, Y., Nwankpa, J.K., and Hu, H.F. Beyond likes and tweets: Consumer engagement 
behavior and movie box office in social media. Information \& Management 54, 1 (2017), 25-37.

[39] Oh, S. and Syn, S.Y. Motivations for sharing information and social support in social media: A comparative analysis of Facebook, Twitter, Delicious, YouTube, and Flickr. Journal of the Association for Information Science and Technology; Hoboken 66, 10 (2015), 2045.

[40] Oviedo-García, Á., Muñoz-Expósito, M., Castellanos-Verdugo, M., and Sancho-Mejías, M. Metric proposal for customer engagement in Facebook. Journal of Research in Interactive Marketing 8, 4 (2014), 327-344.

[41] Pletikosa Cvijikj, I. and Michahelles, F. A Case Study of the Effects of Moderator Posts within a Facebook Brand Page. In A. Datta, S. Shulman, B. Zheng, S.-D. Lin, A. Sun and E.-P. Lim, eds., Social Informatics: Third International Conference, SocInfo 2011, Singapore, October 6-8, 2011. Proceedings. Springer Berlin Heidelberg, Berlin, Heidelberg, 2011, 161-170.

[42] Pronschinske, M., Groza, M.D., and Walker, M. Attracting Facebook 'Fans': The Importance of Authenticity and Engagement as a Social Networking Strategy for Professional Sport Teams. Sport Marketing Quarterly; Morgantown 21, 4 (2012), 221-231.

[43] Pynta, P., Seixas, S. a. S., Nield, G.E., Hier, J., Millward, E., and Silberstein, R.B. The Power of Social Television: Can Social Media Build Viewer Engagement? A New Approach to Brain Imaging of Viewer Immersion. Journal of Advertising Research 54, 1 (2014), 71-80.

[44] Rapp, A., Beitelspacher, L., Grewal, D., and Hughes, D. Understanding social media effects across seller, retailer, and consumer interactions. Journal of the Academy of Marketing Science 41, 5 (2013), 547-566.

[45] Sabate, F., Berbegal-Mirabent, J., Cañabate, A., and Lebherz, P.R. Factors influencing popularity of branded content in Facebook fan pages. European Management Journal 32, (2014), 1001-1011.

[46] Schivinski, B., Christodoulides, G., and Dabrowski, D. Measuring Consumers' Engagement With Brand-Related Social-Media Content. Journal of Advertising Research 56, 1 (2016), 64-80.

[47] Shaheen, M. and Lodhi, R.N. Impacts of social media marketing on consumer decision making process: Descriptive study of Pakistan. Journal of Business Strategies; Karachi 10, 1 (2016), 57-71.

[48] Solem, B.A.A. and Pedersen, P.E. The effects of regulatory fit on customer brand engagement: an experimental study of service brand activities in social media. Journal of Marketing Management 32, 5-6 (2016), 445-468.

[49] Subramaniam, N., Nandhakumar, J., and Baptista, J. Exploring social network interactions in enterprise systems: the role of virtual co-presence. Information Systems Journal 23, 6 (2013), 475-499.

[50] Tsai, W.-H.S. and Men, L.R. Motivations and Antecedents of Consumer Engagement With Brand Pages on Social Networking Sites. Journal of Interactive Advertising 13, 2 (2013), 76-87.

[51] Tsai, W.-H.S. and Men, L.R. Consumer engagement with brands on social network sites: A cross-cultural comparison of China and the USA. Journal of Marketing Communications 23, 1 (2017), 221.

[52] Yang, S., Lin, S., Carlson, J.R., and Ross, W.T. Brand engagement on social media: will firms' social media efforts influence search engine advertising effectiveness? Journal of Marketing Management; Helensburg 32, 5-6 (2016), 526.

[53] Zheng, X., Cheung, C.M.K., Lee, M.K.O., and Liang, L. Building brand loyalty through user engagement in online brand communities in social networking sites. Information Technology \& People; West Linn 28, 1 (2015), 90-106.

[54] A customer engagement cycle for Web 2.0. Strategic Direction; Bradford 28, 10 (2012), 6-8.

[55] Taking the Customer's Point-of-View: Engagement or Satisfaction? Marketing Science Institute, 2013.

[56] How social media aids consumer engagement. Strategic Direction 31, 6 (2015), 21-23.

[57] Friends or Foes: Social Influence, Online Social Networks, and News Consumption. Marketing Science Institute, 2016. 